http://dx.doi.org/10.12775/szhf.2017.033

\author{
AdAM GRZELIŃSKI \\ Nicolaus Copernicus University, Toruń, Poland \\ E-MAIL:GRZELINSKI@WP.PL
}

\title{
Locke on Experience and Notions
}

Among many alleged inconsistencies commentators search for within Locke's philosophy there are two that relate to its very core, namely, the supposed lack of clarity in the scope of meanings attributed to the notions that relate to the objects of human understanding and the ambiguity of the notion of experience. Reducing cognition only to the plane of ideas contained in human mind may - as David Hume later proved - have naturally led to scepticism towards the possibility of cognition of reality "out of the mind". Hence, on the one hand, Locke is sceptical about the cognition of real essences of things, whereas on the other, he postulates the existence of material corpuscles (though he is more careful in this respect than for instance Robert Boyle, his friend and advocate of mechanistic philosophy). The lack of clarity in this case applies to passing from statements concerning the content of thought, to the statements about reality "without the mind". A similar lack of clarity regards the meaning of the term idea, which is sometimes equated with such terms as image, notion, or impression: idea understood as 'any object of understanding', as Locke describes it $(E, I, 1,8, \mathrm{p} .6),{ }^{1}$ seems in any case to be

\footnotetext{
${ }^{1}$ Quotations from Locke's Essay according to the following edition: John Locke. An Essay Concerning Human Understanding. In: The Works of John Locke, London: Printed for C. and J. Rivington, 1824, vol. 1-2. (henceforth $E$; I give the numbers of the book, the chapter, the paragraph, and the page; the first book of the Essay and the first six chapters of the second book are contained in the first volume of the edition).
} 
a rather general term which encompasses various kinds of objects and different terms applied by Locke.

In both cases, one may certainly resort to an explanation by indicating the historic background of the emergence of Locke's empiricism, as exemplified in most recent works by S. Gaukroger, P. Anstey, or P. Walmsley. ${ }^{2}$ His early interest taken in natural sciences and medicine, cooperation with Boyle and the Royal Society must have given solid grounds for the acceptance of corpuscularianism, as this was the most universal standpoint in the then emerging paradigm of natural philosophy, which was not as obsolete as Aristotelianism, or as faulty as the Cartesian theory of vortices. Also, making idea the principal notion of epistemology has its sources in the discussions of that time and Locke's reluctance to use such terms as notion or phantasm that was laden with connotations on account of their application in those days. Locke's way of ideas was to be at the same time a new way of ideas. Nevertheless, interweaving the description of the content of thought with the description of what exists outside the mind, as well as an ambiguous, at first glance, use of these terms leaves the reader of the Essay with the impression that it is somewhat rhapsodic, as if the circumstances in which it was created left their toll on them: this work took a long time to write, it was reedited several times and not finished until Locke's involuntary sojourn in Rotterdam.

The Essay is in many places a demanding read as Locke combined several descriptive orders. Sometimes he writes about ideas as of the images of imagination, sometimes as of notions, and on other occasions, it is difficult to determine if he means the content of thought or existing objects. This ambiguity is easily discernible already when we wish to establish a precise notion of experience which may refer both to the direct description of experiencing things that exist around us, but also to the analysis of the objects of thought themselves (ideas), or it is treated as a result of interacting outside bodies. However, Locke's standpoint becomes clearer if the three ways of describing what is commonly known as experience are separated and the interrelations between them are identified - the commonsensical description as a relation towards that which exists in reality (bodies, other people, and God); psychological, a description of the emergence of ideas and the relations that connect

\footnotetext{
${ }^{2}$ See: Peter Anstey, John Locke and Natural Philosophy, Oxford-New York: Oxford University Press, 2011; Stephen Gaukroger, The Emergence of a Scientific Culture. Science and the Shaping of Modernity 1210-1685, Oxford: Oxford University Press, 2006; Peter Walmsley, Locke's Essay and the Rhetoric of Science, Lewisburg-London: Bucknell University PressAssociated University Presses, 2003.
} 
them, reduced only to mental objects, and a philosophical description which is supposed to prove that all notions are empirical and may be boiled down to simple ideas. Only if we adequately juxtapose them, the reconstruction of the architecture of Locke's philosophical project will be possible. Viewed from this perspective, the contents of the Essay turn out to be surprisingly coherent.

\section{Prelude to the Theory. Descartes' Legacy}

We can trace Locke's quest for a proper term that could be used in the description of the functioning of human understanding in his remark at the beginning of the work, in which he mentions three other terms which idea should replace: species, phantasm, and notion. Various reasons decided about their rejection: the traditional scholastic conception of substantial forms and Aristotelian syllogistics could no longer be the philosophical base for the seventeenth-century natural sciences, Hobbes' phantasm carried materialistic connotations, and notion suggested that objects of human understanding are its constructions, rather than representations of real, existing things. In comparison to them, idea appeared to be a convenient term to conduct the survey into the natural history of human understanding carried out according to the paradigm of natural histories renewed in the XVII century by Francis Bacon.

But also the term 'idea' used by Descartes was a subject of discussions among his followers, Nicolai Malebranche, and Francois Arnauld, the discussions which Locke was well aware of and which can shed some light on the conception found in the Essay. According to Descartes' standpoint, idea has a twofold meaning: on the one hand, it is an object of cogitatio (which allows finding differences among ideas and attribute the reference to things existing independently to some of them), but on the other hand, all of them are modifications of thinking (and hence all can be comprehended under one specific term: idea). ${ }^{3}$

In the discussion originated from this ambiguity, Malebranche attempted to show that ideas are not only objects of thinking, but they also refer to what

${ }^{3}$ See: Jerzy Kopania, Funkcje poznawcze Descartes'a teorii idei. Białystok: Dział Wydawnictw Filii UW w Białymstoku, 1988, p. 68 ff. 
is external to them. Quite unlike Descartes, for Malebranche ideas are also representations:

"I suppose that everyone will grant, that we perceive not Objects that are without us immediately, and of themselves. We see the Sun, the Stars, and infinite number of other Objects without us, and it is not probable that the Soul goes out of the Body, and fetches a walk, as I may say, about the Heavens, to contemplate all the Objects therein. It sees them not therefore by themselves, and the immediate Objects of the Mind, when it beholds the Sun, for example, is not the Sun, but something intimately united to the Soul; and the same thing which I call an Idea. So, by the Term Idea, I mean nothing but that Object which is immediate, or next to the Soul in its Perception of any thing".

Malebranche's definition stresses the difference between an idea as an object (the immediate object of thinking), and the object an idea refers to. To elucidate the way of the reference, he invented the conception of seeing things in God, in which immediately perceived ideas can refer to their archetypes in God's mind. This in turn was tantamount to claiming their independence from human intellectual activity: cognition of ideas was passive, and the whole activity was consequently attributed to God. "And so the Mind may see in God all the works of God, supposing God willing to discover to it what He has in Himself, that represents Them" - concludes Malebranche; hence he can also announce the full "Dependence of our Minds (...) on God in all our Thoughts" 5 .

In his critique of Malebranche's understanding of idea, Arnauld negated the existence of perfections in God's mind - in which case ideas would exist in a sense independently from human understanding and would be passively discovered by it. Admittedly, Arnauld sustained the thesis that "idea" could be understood as an object of thinking, but he also maintained that it is only one of two aspects of idea, the other being modification of thinking. Thus, ideas exist both as objects and as acts. Whereas the first can be called idea in the strict sense of the term, the other he called perception.

"I take perception and idea to be the same thing. It should be observed, however, that this thing, though single, has two relations: one to the mind which it modifies, the other to the thing perceived, in so far as it is objectively in the mind; and that the word perception marks more directly the first rela-

${ }^{4}$ Nicolai Malebranche, The Search after Truth, bk. III, part II, chap. 1, transl. T. Taylor, London 1700, p. 112.

${ }^{5}$ Ibid., bk. III, part II, chap. 6, p. 119. 
tion, and the word idea the second. Thus the perception of a square figure marks more directly the mind as perceiving a square, and the idea of a square marks more directly the square in so far as it is objectively in my mind. This observation is very important for the solution of many difficulties based on an insufficient understanding of the fact that there are not two entities but only the one modification of the mind which contains these two essential relations, for I cannot have any perception which is not both an act of my mind as perceiving and the perception of something as perceived; also nothing can be objectively in my mind (this is what I call idea) which my mind does not perceive."

According to Arnauld, the mistake made be Malebranche boils down to the unjustified analogy between idea and sense perception - idea is not a passively accessible object of thinking (as prima facie objects of sight are) but rather an object of mental activity turning toward it - and as such, it is also a mode of thinking, that is perception.

There are at least two reasons why Locke opposed Malebranche's position. Firstly, it required accepting a kind of gradualist metaphysics, in which archetypes of ideas are more real than ideas. This was in opposition to his pessimism concerning metaphysical reasoning in general. Additionally, such a standpoint was in contradiction to the metaphysics which he might accept as a proper hypothesis fostering the development of natural philosophy. Also the division between the active will and the passive intellect receiving what God allows man to know was something which was inacceptable for him not only for its sterility but also as standing in manifest contradiction with the everyday activity of a natural philosopher: observing and classifying phenomena, generalizing, and drawing conclusions. As we shall see, both faculties - understanding and volition - cannot be separated from each other. In his An Examination of P. Malebranche's Opinion of Seeing All Things in God he summarizes this conception stressing its sterility, if not absurdity:

"I have ideas, that I know; but I would know what they are; and to that I am yet only told, that "I see them in God." I ask how I see them in God? And it is answered, by my "intimate union" with God, for he is every-where present. I answer, if that were enough, bodies are also intimately united with God, for he is everywhere present; besides, if that were enough, I should see

${ }^{6}$ Antoine Arnauld, Des vraies et des fausses idées, Cologne 1683, pp. 36-37, quoted by Robert McRae in: "Idea' as a Philosophical Term in the Seventeenth Century", Journal of the History of Ideas, 26, 1965, p. 179. 
all the ideas that are in God. No, but only those that he pleases to "discover". Tell me wherein this discovery lies, besides barely making me see them, and you explain the manner of my having ideas: otherwise all that has been said amounts to no more but this, that I have those ideas that it pleases God I should have, but by ways that I know not; and of this mind I was before, and am not got one jot farther."

Locke follows Arnauld as he refers to the ontic status of ideas being not only objects of thinking but also perceptions understood as modifications of thought. Consequently, he writes that „whatever idea was never perceived by the mind, was never in the mind. Whatever idea is in the mind, is either an actual perception; or else, having been an actual perception, is so in the mind, that by the memory it can be made an actual perception again $(E, I, 4,20$, p. 69), and adds that ideas are "bare appearances or perceptions in our minds" ( $E$, II, 32, 1, p. 407). By stating this, he seems to accept Arnauld's understanding of ideas. ${ }^{8}$

\section{Locke on Ideas and Notions}

Before we turn to the issue of the significance of this dual-aspect approach to the notion of "idea", let us first clear up the terminology used in the Essay, for on many occasions their usage seems to be unclear - the prime example being the abovementioned identification of idea with appearance and perception.

Although in Locke's description of experience idea plays an essential role, he more often than not uses three other notions: impression, image, and notion, depending on which aspect of the meaning of idea he is concerned with. ${ }^{9}$ He uses the term 'impression' primarily in relations to the origin of the objects of thought. This term is largely in use in the first book of the Essay: the criticism of nativism is about the objection against the innate nature of impression (cf: $E, \mathrm{I}, 2,1-2, \mathrm{p} .13-14)$ in the sense that one source of objects of

\footnotetext{
${ }^{7}$ J. Locke, Works, London 1824, vol. 8, p. 223.

${ }^{8}$ On the usage of the term idea in seventeenth-century English philosophical works see: John Yolton, John Locke and His Way of Ideas, London: Oxford University Press, 1956, p. 86 ff.

${ }^{9}$ On Locke's dependency on Gassendi and Descartes see: Michael Ayers, John Locke, London: Routledge, 1991, vol. 1, p. 45 ff.
} 
thinking is the sensual and reflexive experience that is being revealed. Similarly, when in book two Locke writes about the origin of simple ideas, he indicates that their source is the sensual impressions, and since the origin of ideas other than the interrelations of outside bodies is not possible, an impression in a narrowed sense can be identified with the activity of a bodily sensual organ - its description belongs to physiology. „It is about these impressions made on our senses by outward objects, that the mind seems first to employ itself in such operations as we call perception, remembering, consideration, reasoning, \&c." (E, II, 1, 23, p. 91). In this sense, this notion is most closely linked to its etymological meaning which relates to imprinting (from Latin im-premo).

The second notion used by Locke interchangeably with idea is image. Thus, we read about receiving "a variety of images" by the soul (E, II, I, 15, p. 86) and reflecting "the images or ideas which the objects set before it do therein produce" (E, II, I, 25, p. 92); however, Locke adds that ideas are not in a strict sense "images and resemblances" of something that is embedded in the object $(E, \mathrm{II}, 8,7, \mathrm{p} .111)$ or "images or representations of existing things" ( $E$, II, 30,2, p. 394). The relation between external bodies and the organs of sense is of causal character, so it would be meaningless to talk about a similarity between ideas and things. In the Essay, 'image' has a twofold meaning: a sensual picture and a likeness. In the former case with the picture, one may refer to ideas which are identical to a simple sensual content that is created under the influence of external stimuli; yet, what makes the 'image' distinct from 'impression' is that the former is purely mental: when Locke says that idea is an image he does not refer to its source but only to the appearance of the sensual content. Making use of that notion also points to its apparently passive nature; in a sense which will be discussed shortly afterwards, the image refers only to sensual data. Although it is formed under the influence of external stimuli, the relation between mental sensual ideas and bodies outside reason is not based on similarity; therefore, ideas may not be regarded as images of bodies and Locke separates them in this sense. Establishing the nature of this relation extends beyond the plane of bare ideas and is possible only on the grounds of natural philosophy and metaphysics.

Last but not least, the third term which Locke equates with idea, is notion, with the reservation that the use of this term points to purely intelligible character. Locke uses it either in relation to all notions in the general sense when he writes that "the originals of our notions" should be examined ( $E$, II, 12, 8, p. 146), or he treats notions as the figment of the mind estab- 
lishing that notions relating to simple ideas may not be defined, adding that without a direct experience "all the words in the world cannot [give] any notion of it" ( $E$, II, 9, 2, p. 121). Contrary to images, whose perception is conceived as a passive state of mind, the term notion points to the activity of the understanding; notions are very often apparently non-empirical in nature, like the notion of spirit, God (E, III, 6, 11, p. 481) or the scholastic species (E, III, 6, 17, p. 485). Hence, in the order of presentation assumed in the Essay, ideas may be equated with notions either initially, before ideas are analysed, when their status is yet to be established, or when this analysis demonstrates the manner in which these notions are formed. In both cases they are objects of human understanding, just like the ideas introduced by Locke; however, in a stricter meaning, notions result from complex operations of understanding and in this aspect they are in opposition to images (hence Locke writes sometimes about creating new notions ( $E$, III, 6, 51, p. 509)).

There is one more reason for equating the terms idea and notion. In Locke's analysis of experience - grouping of ideas into respective kinds and in his determinations of relations between them - the division into the functions of experience (sensuality, memory, imagination, or mind) is not of paramount importance. Thus 'idea' is not a certain image of the senses, memory, or imagination which can later be accurately expressed by means of notions. Locke's declaration from the first chapters of Essay that idea is on a par with notion and just like the notion it can be plain, clear (E, I, 1, 4, p. 3), distinct, and perfect ( $E$, II, $1,7-8$, p. 80-81) partially allows for the equation of the both terms. Since the very start, Locke's description of ideas invokes the objects of understanding that have a nature of notions. Idea - therefore also a notion - is now an outcome of an operation of a human mind - its propensity to a proper selection of direct data from experience - "that vast store which the busy and boundless fancy of man has painted on it, with an almost endless variety" (E, II, 1, 2, p. 77).

\section{Three Ways Experience Could Be Understood}

The dual-aspect character of ideas, the fact that they are both objects of thinking and its acts, is best expressed in Locke's fundamental distinction between the ideas of sense and the ideas of reflection. The distinction is the first 
attempt to draw the line between the activity of human understanding, and its reception of what is given - its passivity. The both aspects of experience, though separate, are at the same time two indispensable sides of one experience. A more precise line of distinction between them is drawn as a result of subsequent divisions indicated by Locke: between simple and complex ideas, and between ideas of modi, relations, and substances. All of them allow to define the activity of understanding, and the scope of their reference to what exists out of the mind. In this process of estimation, the difference between the activity of human reason and its passivity, and in defining of which objects of our thinking can refer to reality, we can hear the echo of the discussions within Cartesian philosophy.

However, the passivity does not mean (or at least does not necessarily mean) bare receptivity. It is only the understanding of experience which is not yet analyzed philosophically that allows us to claim that a real object, existing out of human mind, is reflected passively, as in a mirror. Though in everyday, commonsensical approach to experience we deal with the results of such 'reflecting', the nature of the 'reflection' turns out to be the concatenation of various processes which - when objectified - become the ideas of reflection: perception, retention, memory, giving names, etc. What was supposed to be a given object is a result of several particular processes and only by turning backwards towards the very beginning of the processes - to the first one called perception we can find the passive element of experience - something that is only perceived - the element which due to the lack of a proper name we can call a dynamic field of experience, not yet split into fragments or atomized into separate objects - the latter being the result of retaining, remembering, comparing, abstracting, etc. This process of separation of certain fragments of experience, this objectification is the result of an active attitude of human mind: directing its attention towards certain parts of the experience. Thus, the attention can be more or less focused: from a mere reverie, when ideas "float in the mind" ( $E$, II, 19, 1, p. 213) to the state in which "the mind with great earnestness, and of choice, fixes its view on any idea, considers it on all sides, and will not be called off by the ordinary solicitation of other ideas" which we call "intention, or study" (ibidem). Passivity of mind can be attributed only to the act of perceiving, independent from volitional activity. Locke admits: "For in bare naked perception, the mind is, for the most part, only passive: and what it perceives, it cannot avoid perceiving" (E, II, 9, 1, p. 121). Even simple ideas are products of processes of reflection collectively called thinking. 
This leads directly to my next point, for the analysis of reflection, in which perception is but one of various processes, can be the ground of differentiation of three complementary ways experience is referred to in Locke's Essay.

Firstly, experience can mean the reference to what exists out of the mind (Descartes would add: what exists formally) - natural bodies that surround us, other people (finite intelligences) and God. But this commonsensical standpoint must be problematized if we are to follow Locke's new way of ideas, since what is real is mediated by ideas, and this mediation comes down not to an image-like analogy between ideas and real things, but rather to the fact that objects of our experience are mental constructions. Such are nominal essences of things, but even corpuscles with their primary qualities - the real elements of things - are no more than a hypothesis useful in experimental natural philosophy. This new approach also reveals several obscure presuppositions on which the commonsensical understanding of experience rests, such as the existence of things independent of mental processes and the existence of some relation that join the things and their mental images. The presuppositions require elucidation and investigation into what and to what extent we can know about the nature of bodies which affect us exciting some ideas in us. Locke does not cease to be a realist, and he does not deny the existence of things around us, other intelligences, or God. But between this commonsensical realism - so to speak - a quo, and the realism ad quem, the former being at the beginning of philosophical endeavor, and the latter at its end - lies the vast field of Locke's investigations - the field of ideas and of knowledge. The characterization of the kinds of ideas (the objects of consciousness) forms the grounds of knowledge: of natural philosophy (justifying natural history) and of practical philosophy and their metaphysical foundations.

Thus, we moved to the second, narrower understanding of experience, understood as the sum of objects of direct awareness: both the elements of sense perception, out of which we build the notions, and also several operations of human understanding which themselves are its objects. In this narrower sense, the term experience refers to all objects of consciousness, ranging from simple ideas of sense and of reflection to the most abstract notions.

Thirdly, treating experience as the source of all knowledge is tantamount to a philosophical programme in which all notions can be derived from ideas all of them are empirical and are either simple ideas or can be reduced to them as their combinations. We can follow the formation of concepts out of simple elements of experience (in its abovementioned narrow sense). For 
example, when Locke discusses eternity and time (quite abstract notions), he adds:

"And I believe we shall find, if we warily observe the originals of our notions, that even the most abstruse ideas, how remote soever they may seem from sense, or from any operations of our own minds, are yet only such as the understanding frames to itself, by repeating and joining together ideas, that it had either from objects of sense, or from its own operations about them: so that those even large and abstract ideas are derived from sensation or reflection, being no other than what the mind, by the ordinary use of its own faculties, employed about ideas received from objects of sense, or from the operations it observes in itself about them, may and does attain unto" ( $E$, II, 12, 8, p. 146).

But this reconstructing the formation of notions which, when revealed, can be the ground for communication among individual people is of crucial, but at the same time, limited importance. It is crucial, for although all people are reasonable and they have their share in human reason, at the same time they are only its imperfect depositaries burdened with various deficiencies. Only by finding the grounds of notions in common experience can the means of communication be established.

The three descriptions of experience can be called commonsensical, psychological, and philosophical, respectively, and all the three can be found in the Essay. Though sometimes vague, the difference between the psychological and the philosophical approach to experience is crucial: although the psychological approach reveals the forming of concepts, the philosophical understanding of experience underlines various functions notions can perform in knowledge. And the psychological approach, however new and important, is no more than an introduction to the problem of knowledge, in which natural philosophy formulates hypotheses. One of them, and the most probable one for Locke, is the corpuscularian hypothesis (and in many places Locke admits it is no more than a useful hypothesis, and even refers to the Newton's theory of gravitation in the 1700 edition of the Essay as to another one). From this point of view, Locke can be seen - as it is sometimes - as a forerunner of fallibilism in science. ${ }^{10}$

\footnotetext{
${ }^{10}$ Peter Anstey, John Locke and Natural Philosophy, p. $70 \mathrm{ff}$.
} 


\section{Conclusion}

One of the aims of Locke's doctrine of ideas was to give the grounds for knowledge, especially descriptive and speculative cognition of nature, and for a rational discussion on practical issues of religion and politics. By introducing the new understanding of "idea" and referring it to experience of individual people, Locke established a new paradigm for knowledge: no individual thinker could claim the universal validity of their experience and their beliefs. Only when the experience is mediated by language and the judgements are formulated, knowledge can be attained. Locke's pessimism concerning the knowledge of real essences of things and his frequently repeated admonition that it is only ideas that "our knowledge is only conversant about" ( $E$, IV, 1,1, p. 58) makes it necessary to reformulate the commonsensical thesis of reflecting the world in human experience. Ideas do not refer to things themselves, independent from the process of cognition, though they represent things and their qualities. But any characteristic of things is given only within the realm of knowledge. Locke's new approach to metaphysics is tantamount with claiming that the utmost we can do to describe things themselves is to use the notion of "substance" (in the seventeenth-century, post-Cartesian meaning of the term). However, we have to realize that "of substance, we have no idea of what is, but only a confused obscure one of what it does" (E, II, 13, 19, p. 156). Thus, the cognitive relation joins ideas and object constructed in knowledge (both in their descriptive, "historical" sense, and the speculative one). This claim of the primacy of cognition over existence opened the road to later empiricism of Berkeley and Hume, but also to the Kantian turn in philosophy.

The multifold understanding of experience, the combining the commonsensical, the psychological, and the philosophical interpretation of experience might give an impression that by opposing traditional seventeenth-century philosophy and creating his new way of ideas in his Essay Locke opened too many doors with one kick. And later interpretations given by Berkeley, Hume, or Reid might prove the validity of such a statement. However, I guess Locke knew what was behind each of these doors. ${ }^{11}$

${ }^{11}$ The research was carried out as a part of the National Science Centre (NCN) grant (UMO-2012/07/B/HS1/01619). 


\section{References}

Anstey, Peter (2011): John Locke and Natural Philosophy, Oxford, New York: Oxford University Press.

Ayers, Michael (1991): John Locke. London: Routledge.

Gaukroger, Stephen (2006): The Emergence of Scientific Culture. Science and the Shaping of Modernity 1210-1685. Oxford: Oxford University Press.

Kopania, Jerzy (1988): Funkcje poznawcze Descartes'a teorii idei. Białystok: Dział Wydawnictw Filii UW w Białymstoku.

Locke, John (1824): An Essay Concerning Human Understanding. In: The Works of John Locke, London: Printed for C. and J. Rivington, vol. 1-2.

Locke, John (1824): An Examination of P. Malebranche's Opinion of Seeing All Things in God. In: The Works of John Locke, London: Printed for C. and J. Rivington, vol. 8 .

Malebranche, Nicolai (1700): The Search after Truth. transl. T. Taylor, London.

McRae, Robert (1965): "Idea' as a Philosophical Term in the Seventeenth Century", Journal of the History of Ideas, 26.

Walmsley, Peter (2003): Locke's 'Essay' and the Rhetoric of Science. Lewisburg, London: Bucknell University Press - Associated University Presses.

Woolhouse, Roger (2009): Locke. A Biography. New York: Cambridge University Press.

Yolton, John (1956): John Locke and His Way of Ideas. Oxford: Oxford University Press.

\section{Summary}

In the present paper, I analyze the terminology John Locke used in his description of experience. Although he makes idea the principal term, also image, impression, and notion frequently appear in his Essay. Their meanings and interrelations are rooted in the seventeenth-century discussion in post-Cartesian philosophy which was the reason for using them in various contexts by Locke. Additionally, I suggest that three different approaches to experience can be found intermingling in Locke's Essay: the commonsensical, the psychological, and the psychological one. Depending on a perspective taken in various parts of the work, they complement one another. Distinguishing them makes it possible to appreciate the coherence of Locke's philosophy in which the individuality of individual experience is made the ground of objective knowledge.

Keywords: John Locke, empiricism, experience, idea, notion, epistemology, natural philosophy 